\title{
Transgresje. Przenikania. Synchroniczność. Uwagi o wyobraźni chorwackiej i serbskiej awangardy literackiej
}

\begin{abstract}
Czapik-Lityńska Barbara, Transgresje. Przenikania. Synchroniczność. Uwagi o wyobraźni chorwackiej i serbskiej awangardy literackiej (Transgressions. Penetrations. Synchronicity. Comments on the Imagination in the Croatian and Serbian Literary Avant-garde). "Poznańskie Studia Slawistyczne" 18. Poznań 2020. Publishing House of the Poznań Society for the Advancement of the Arts and Sciences, Adam Mickiewicz University, pp. 83-101. ISSN 2084-3011.

The article discusses selected problems of the image, imagination and the ideological-aesthetic consciousness of the avant-garde in Croatian and Serbian literatures. Inspired by the ideas of modern Europe and opened to experiment, transgressions and mental function of the artistic language, it created an autonomous world of imagination. Utopian theories of reality evaluated from expressionistic conceptions of penetration of the world if matter and spirit, Earth and universe to surrealistic conceptions of over-reality.
\end{abstract}

KEYwords: imagination; literary constructions of imagination between culture and nature; penetration

Psychika i materia istnieją w tym samym świecie, ściśle ze sobą granicząc; w przeciwnym razie wszelkie wzajemne współdziałanie między nimi byłoby przecież niemożliwe

C.G. Jung, Aion

O awangardzie napisano setki książek i artykułów. Także o awangardach słowiańskich, w tym o chorwackiej i serbskiej, którymi slawiści polscy zajmowali się dość intensywnie (m.in.: Maria Dąbrowska-Partyka, Julian Kornhauser, Krystyna Pieniążek-Marković, Patrycjusz Pająk, Bożena Tokarz, by wymienić tylko polskich slawistów i autorów książek poświęconych twórcom awangardy). $\mathrm{W}$ ich pracach (także w moich) czytelnik 
odnajdzie pełną bibliografię. Opracowano historię kierunków i wybrane zagadnienia poetyki twórców wybitnych. Nie zamierzam powtarzać faktów i prawd już opisanych. Nie będę też przypominać pozycji bibliograficznych, poza tymi, które stanowią sfunkcjonalizowane dopełnienie treści artykułu. Wydaje się, że badania nad awangardą, choć nadal trwają, to prezentują ciekawe i zróżnicowane osiągnięcia.

Niniejszy artykuł jest przeznaczony dla czytelnika obeznanego z ważniejszymi kontekstami literatury przedmiotu. Podstawowym celem jest zwrócenie uwagi na transgresyjny, dynamiczny charakter wyobraźni, z uwzględnieniem fenomenu synchroniczności. Wyobraźnią awangardy zajmowałam się w różnych perspektywach, zwłaszcza w kontekście świadomości utopijnej i archetypicznej. Nie wycofuję się z dawnych interpretacji i ustaleń, ale brakuje mi w nich jednoznacznego podkreślenia, że awangarda łamie granice, jest otwarta, procesualna, ruchliwa, zaskakująca, niekiedy chaotyczna, niekiedy aporetyczna, obca, a jednocześnie powiązana z życiem i człowiekiem. To, co niezmiennie przyciąga moją uwagę, to pasja poznawcza awangardy, związana nie tyle z racjonalnymi poetykami i literackością, ile właśnie z wyobraźnią i jej irracjonalną specyfiką. Interesuje mnie dążenie do poszerzenia świadomości, do wyrażania niewyrażalnego, do przekraczania granic i pól semantycznych. Estetyczne i poznawcze ambicje awangardy były niezwykłe, szokujące i kontrowersyjne. Taka też była jej sztuka. Z jednej strony oryginalna, fascynująca, dziwna, epifaniczna, hermetyczna i elitarna, z drugiej natomiast zwykła i zwyczajna, nasycona problemami bytu i rzeczywistości ludzkiej, społecznej, usiłująca paradoksalnie przekreślić granice kultury wysokiej, zdemokratyzować ją tak, by była bliska każdemu człowiekowi jako naturalna aktywność twórcza.

W przeglądowym szkicu nie uda się przywołać wszystkich ważnych problemów, nazwisk i tekstów. Dlatego wybiorę tylko niektóre, najlepiej ilustrujące semantyczną osobliwość językowego i obrazowego wyrażania transgresyjnej wyobraźni i myśli awangardy, zwłaszcza w jej ostatniej nadrealistycznej fazie. Nadrealizm - podobnie jak Wielka Awangarda - jest etapem historycznie zamkniętym, ale jego oddziaływania są trwale obecne w sztuce poawangardowej. Oznacza to przenikanie idei, obrazów, motywów oraz kontynuowanie awangardowych technik i sposobów konstruowania myśli (także wizji rzeczywistości), takich jak m.in. symultanizm, 
kolaż, ejdetyzm. Nowa estetyka preferowała formę otwartą, adekwatną do wprowadzonego przez awangardę paradygmatu wyobraźni, zorientowanego na intuicję i kreację, dynamizację energii psychicznych i twórczych, podmiotowych, ale i kosmocentrycznych. Awangarda kierowała się intuicją, instynktem (koncept serbskich ekspresjonistów i nadrealistów, ale i chorwackiego pisarza Miroslava Krležy), energiami wyobraźni, marzenia i snu. Jej najbardziej irracjonalne skrzydło było zafascynowane powiązaniami procesów twórczych z nieświadomością i jej archetypowymi strukturami. Według Krytycznego słownika analizy Jungowskiej wyobraźnia to „strumień lub suma obrazów i idei w nieświadomej psyche, tworzących najbardziej dla niej charakterystyczną aktywność. [...] Głównymi częściami składowymi wyobraźni są obrazy, które należy generalnie rozumieć jako odnoszące się do elementów aktywnych w psychice" (Samuels, Shorter, Plaut, 1994, 224-226). Dlatego interpretacja obrazów, zwłaszcza poetyckich, ma istotne znaczenie dla zrozumienia podmiotu doświadczenia sztuki, czyli dzieła. Nadrealizm w poszukiwaniu informacji źródłowej, bytowej, zredukował role podmiotu autorskiego, a wraz z zapisem automatycznym wprowadził podmiot mediumiczny, rzucający nowe światło na przestrzeń struktur systemowych - estetycznych i bytowych. Badacze zazwyczaj podkreślają autonomiczny charakter komunikatów i gier awangardy, niezależny i wolny. Tymczasem język połączony z psyche i eksploracjami wyobraźni zakorzeniał się w rzeczywistości materii i rzeczywistości myśli, wyrażanych znakami zanurzonymi w świecie innych znaków. Przenikania obrazów i znaków stały się dla interpretatorów nowym doświadczeniem i prawdziwym wyzwaniem. Bardzo skomplikowanym, bo przełamującym wcześniejsze wyobrażenia o literaturze i sztuce. Lekturze tekstów awangardy i badaniu literackości towarzyszy raczej dekonstrukcyjna myśl ponowoczesności, aniżeli strukturalistyczna nowoczesności. Przy tym niektóre teksty wykraczają poza ramy tradycyjnie rozumianej literatury i są raczej antyliteraturą. Artyści awangardy dość wyraźnie i dość jednoznacznie wyjaśniali w manifestach i programach swój bunt przeciw literaturze.

Chorwacka i serbska awangarda kroczyła od ekspresjonizmu do nadrealizmu. Taka była zasadnicza linia rozwojowa. Silny ekspresjonizm ewoluował w kierunku wyobraźni nadrealistycznej. Po drodze pojawiały się mniej lub bardziej rozbudowane efemerydy literackie, jak futuryzm, 
dadaizm, hipnizm, zenityzm, konstruktywizm. Badacze najwięcej uwagi poświęcili ekspresjonizmowi i jego rozmaitym wariantom. Był bowiem prądem najsilniejszym, najbardziej rozwiniętym, obejmującym wszystkie literatury Jugosławii. Nie bez powodu mamy polskie opracowania twórczości Miroslava Krležy, który w okresie międzywojennym uchodził za ekspresjonistę i realistę dialektycznego. Pisali o nim Jan Wierzbicki, Patrycjusz Pająk, Julian Kornhauser. Twórczości Antuna Branka Šimicia, uznanego za reformatora nowoczesnego wiersza chorwackiego poświęciła rozprawę Krystyna Pieniążek-Marković (2000). Ivo Andricia, którego pierwsza faza twórczości oznaczała ekspresjonistyczny egzystencjalizm, przedstawiał - w perspektywie oglądu całej twórczości - najpierw Jan Wierzbicki, później Kazimierz Żórawski. Ale i pozostałe kierunki awangardy prezentują równie ciekawe i kontrowersyjne zjawiska, nawet bardziej intrygujące, zaskakujące, dziwne. Omawiają je: Maria Dąbrowska-Partyka (zwłaszcza problematykę twórczości Tina Ujevicia), Aleksander Naumow (zenityzm). Mimo że nie uwzględniam awangardy słoweńskiej, to warto zwrócić uwagę na twórczość Srečka Kosovela, któremu poświęciła obszerną rozprawę Bożena Tokarz (2004). W szczególności rozdział Poetyckie doświadczenie ruchu może stanowić cenny punkt odniesienia do awangardowego doświadczenia transgresji wyobraźni i rozumienia świata, doświadczenia wspólnego, ale zawsze różnego w indywidualnych realizacjach artystycznych.

Najbardziej hermetyczny i obcy, najbardziej atakowany i niezrozumiany był nadrealizm i jemu w swoich pracach poświęciłam najwięcej uwagi. Wprawdzie - według tradycyjnego pojmowania historii literatury - nie pozostawił dzieł wybitnych, którymi mierzy się osiągnięcia kultur narodowych, ale odegrał ważną rolę w procesie budowania nowych języków wyrażania artystycznego i konceptualizowania rzeczywistości. W sferze wyobraźni oferował wolność, zarówno twórcy, jak i odbiorcy, czyniąc obu kreatorami myślenia i tworzenia, konstruktorami świata, znaczenia i sensu. Zasadniczo trudno nie zgodzić się z krytykami deprecjonującymi znaczenie zapisu automatycznego i twórczości nadrealistów, ale jako cierpliwa obserwatorka tych tekstów jestem ich ciągle ciekawa. Powtórzę jednak za Zbigniewem Bieńkowskim: „Nie potrafię wymienić dzieła nadrealizmu, które by zawarło ową programową pełnię poznawczą, które by odbijało irracjonalne i ukazywało skalę nadrealistycznego zamiaru. 
Zamiar był tak olbrzymi, tak wielki i bezinteresowny, że wszelkie jego realizacje wydają się nikłe" (Bieńkowski, 1974, 68). Problemem jest nie tyle pojedyncze dzieło, ile jego interferencje z innym, których specyfika jest nierozpoznana i tajemnicza, skutecznie uniemożliwiająca rozumiejącą lekturę i formułowanie jednoznacznych wniosków. Mam tu na uwadze między innymi synchroniczność, której nie sposób wyjaśniać przy pomocy badania literackości. Synchroniczność to jednoczesność występowania pewnych procesów lub zjawisk, często pozornie niczym niepowiązanych, co trudno jest wyjaśnić w zadowalający sposób. Daryl Sharp powtarza za Jungiem, że jest to ,zasadniczo tajemny związek między psyche człowieka a światem materialnym, oparty na tym, że w gruncie są one jedynie różnymi formami energii” (Sharp, 1998, 158). Nadrealiści uznawali je (procesy, zjawiska, energie) za prezentacje ,mikroodbicia nieantynomicznej surréalité" (Janicka, 1985, 111). W koncepcie nadrzeczywistości było miejsce na magiczne przenikania i na przypadek obiektywny, który z kolei tłumaczono jako konieczność zewnętrzną płynącą z podświadomości, w której krzyżuje się to co zewnętrzne i obiektywne z tym co wewnętrzne i subiektywne (v. Janicka, 1985, 110-122). Pojęcia synchroniczności i przypadku obiektywnego są pokrewne.

W tekstach nadrealistów, zwłaszcza tych wyzyskujących zapis automatyczny, zachwiane zostały: linearność, przyczynowość, przewidywalność, jednoznaczność, prawdopodobieństwo. W zamian pojawił się nielinearny tok narracji, chaotyczna kompozycja, obrazy ejdetyczne wskazujące na przypadkowe powiązania, dziwne i pozornie bezsensowne, nielogiczne. Jedność rozbitego świata przedstawionego, rozbitego języka bywa warunkowana kompozycją, synchronicznością i symultanicznością, które umożliwiają ruch, transgresję, przenikanie oraz spotkania różnego, innego, równoległego. Według synchronii akauzalnej Junga, między wydarzeniami, sytuacjami, faktami istnieją związki inne niż przyczynowo-skutkowe. Znajomość teorii synchroniczności czy to w ujęciu Junga, czy w ujęciu nadrealistów w niewielkim stopniu wspomaga rozumienie synchroniczności w dziele. Żeby ją wyjaśniać, najpierw trzeba ją zauważyć, a następnie odnaleźć właściwe dla zdarzenia synchronicznego konteksty. Nawet Jung miał problem z interpretacją synchroniczności i oniryzmu. Powtórzę za Jolandą Jacobi, że ,[b]adania Junga nad synchronicznością przyczyniły się do powstania szeregu nowych problemów, które wymagają dalszych 
badań i dyskusji” (Jacobi, 1996, 74). A tymczasem synchroniczność jest i pojawia się w twórczości współczesnej, zaskakując nas dziwnością i tajemniczością. Mam tu na myśli filmy Kieślowskiego, współczesną piosenkę co ambitniejszych zespołów muzycznych i oczywiście poezję, reprezentowaną nie tylko przez awangardę. Poeci chorwaccy wyzyskiwali doświadczenia snu i w ten sposób poszerzali artystyczną percepcję o perspektywę oniryczną (v. Czapik-Lityńska, 2012). Poeci serbscy czynili to już w romantyzmie. Synchroniczność pojawia się w poetyckich wizjach rzeczywistości Krzysztofa Kamila Baczyńskiego, w poezji Artura Międzyrzeckiego, Mirona Białoszewskiego (symptomatyczny wiersz Roztam $w$ barze mlecznym $z$ niespodziewanem) i innych tropicieli dziwnych powiązań słów z rzeczywistością zewnętrzną i wewnętrzną. Awangarda i sztuka współczesna prezentują przenikania zachodzące w szeroko rozumianej rzeczywistości, charakterystycznej dla modeli wyobraźni awangardowej i obsługujących ją języków.

Przenikania w rzeczywistości i w rzeczywistości psychicznej łączy nie tylko zjawisko synchroniczności, ale dla awangardy jest ono ważne, bo umożliwia wejście w to, co nie jest możliwe do zrozumienia. Słowo nemoguće (niemożliwe) jest zresztą jednym ze słów-kluczy nadrealizmu. W lutym 2019 roku odbyła się w Belgradzie konferencja pod hasłem „Poetika nemogućeg" poświęcona głównie twórczości nadrealistów. Nie miałam możliwości zapoznania się z materiałami, ale jestem ich bardzo ciekawa. Mam też nadzieję, że synchroniczność wraz z kontekstami psychoanalizy została $\mathrm{w}$ tej poetyce uwzględniona. Nie można bowiem pomijać zagadnień związanych z otwarciem nadrealizmu na irracjonalne, na podświadomość czy nieświadomość. Historia (także sfera światopoglądu i estetyki) serbskiej awangardy i nadrealizmu została już dobrze opracowana. Poetyka w mniejszym zakresie. Olga Tokarczuk - niekryjąca swoich fascynacji tekstami Junga - pisze: „Dla mnie zdarzenia synchroniczne pokazują, że rzeczywistość jest poprzerastana sensami i znaczeniami istniejącymi w świecie niejako niezależnie od ich postrzegania" (Tokarczuk, 2019, 21). Bardzo podobnie myśli awangarda, której podejście do synchroniczności nie jest wszak racjonalne, jak np. w konwencji realizmu magicznego, ale irracjonalne i przez to znacznie trudniejsze do objaśnienia.

Aby synchroniczność zauważyć, należy rozpoznać, do jakiej koncepcji całości nawiązuje (ale to jest temat na inny artykuł), co otwiera pole do 
bardziej złożonych spekulacji filozoficznych. W tym miejscu przypomnę, że w oparciu o awangardowe koncepcje rzeczywistości, wielu rzeczywistości, nadrzeczywistości, tworzono wizje artystyczne, których dziwność i niejednoznaczność wymagała krytycznego komentarza. Sami poeci wypowiadali się raczej niechętnie, traktując swoje dziwne zapisy w sposób mniej lub bardziej poważny, widząc w eksperymentach artystycznych zabawę, grę, fantazjowanie, niekiedy prowokację. Zofia Rosińska zwróciła uwagę, że w sztuce współczesnej (I połowy XX wieku, a więc w dobie historycznej Wielkiej Awangardy) przetrwało „niezbyt zrównoważone, maniakalne doświadczenie mistycznej jedności” (Rosińska, 1985, 176). Psychoanalitycy w interpretacji trudnych wizji często odwołują się do zjawisk z pogranicza neurozy. To, co oglądamy jako rozbity obraz świata, traktują w kategoriach wiedzy psychiatrycznej. Niektóre obrazy Picassa uznawano wręcz za schizofreniczne. Nadrealiści serbscy wyzyskiwali paranoję (czy raczej symulację paranoi) jako sposób myślenia umożliwiający łączenie realnego i racjonalnego z irracjonalnym. Serbska badaczka Jelena Novaković swoją książkę o poetyce nadrealizmu zatytułowała $\mathrm{Na} \mathrm{rubu}$ halucinacija (Novaković, 1996). Filozofia hermeneutyczna interpretuje obrazy halucynacyjne jako obrazy błądzące, ale też jako językowe (artystyczne) konkretyzacje zmieniającej się rzeczywistości, której tropy (i sygnały) wrażliwy artysta utrwala w dziele literackim bądź malarskim. Tym samym zwraca uwagę na procesualność bytu i jego powiązania z człowiekiem. Oczywiście można ich nie dostrzegać i ograniczyć się do opisywania literackości.

W literaturze awangardy chorwackiej koncepcje całości są artystycznymi konstrukcjami, wykraczającymi poza granice racjonalnej percepcji. Poetycka wyobraźnia Tina Ujevicia kreowała całość bytu na sposób utopijny, typowy dla awangardy. Jego poezję cechuje kosmocentryzm. Człowiek jawi się jako ważny element wielkiej całości i uczestnik procesu jej nieustannego budowania. Spoczywa na nim obowiązek rozumienia bytu i współpracowania z nim. W wierszu Kozmogonije podmiot liryczny powiada „Uvijek je glavna dužnost: s neba pročitati sat” (Ujević, 1979, 98). Świat Ujevicia to całość-sieć powiązań, konstrukcja i proces, w których uczestniczy poeta i każdy człowiek. Rzeczywistość jest strukturą żywą, na sposób panteistyczny pełną znaków i zdarzeń, które moglibyśmy nazwać synchronicznymi. 
Także Šimicia wizja całości nawiązuje do idealistycznego, poniekąd zmityzowanego dyskursu, co jest bardziej widoczne w jego manifestach i esejach, aniżeli w poezji, która wydaje się konkretna, uziemiona bytowo. Poeta jest uznawany za twórcę nowoczesnego wiersza i nowatorskiej formy, która zaskakuje oryginalnymi metaforami i obrazami. Świat przedstawiony jest zwyczajny, a zarazem niezwykły, pełen ruchu, przenikania, przeobrażeń, zaskoczeń. Niezwykłość świata i jego przeobrażeń jest niezrozumiała, ale możliwa do uchwycenia przez poetów rejestrujących poruszenia rzeczywistości:

\footnotetext{
Pjesnici su čuđenje u svijetu

Oni idu zemljom i njihove oči

velike i nijeme rastu pored stvari

Naslonivši uho

na ćutanje što ih okružuje i muči

pjesnici su vječno treptanje u svijetu

(Pjesnici, Šimić, 1988, 5).
}

Poeta jest przedstawiony jako zadziwiony światem, odczytujący ciszę bytu przy pomocy ucha i oka, które to zmysły mogą się intensyfikować w akcie percepcji. Šimić rozważa możliwości poznawcze poezji i poety, który jest ciałem percypującym, przenikającym i transformującym. Dysponuje szczególnym ustrukturowaniem, wrażliwością i talentem, możliwością zamiany kodów artystycznych i możliwością transformacji komunikatu oraz ingerowania w sfery duchowe bytu (v. Pieniążek-Marković, 2000). Jest świadkiem i uczestnikiem zachodzących wokół metamorfoz. Pozycja poznawcza oscyluje między panenteizmem a panpsychizmem.

Warto zwrócić uwagę, że Miroslav Krleža, który nie przepadał za awangardą, sformułował koncepcję twórczości, w której dowartościował biologiczne aspekty w akcie twórczym. Doceniał też poglądy estetyczne Marka Risticia, animatora ruchu nadrealistycznego w Belgradzie. W 1933 roku, w Przedmowie do „Motywów znad Drawy” Krsta Hegedušicia chorwacki pisarz jednoznacznie opowiedział się za sztuką wyswobadzającą intensywne przeżycia i emocje podmiotu, kierującego się nie poetykami i programami, ale instynktem, podświadomością, subiektywną wrażliwością, biologicznymi drogowskazami wpisanymi w cielesność: 
Tworzyć z talentem znaczy: poddawać się mocnemu instynktowi życia, a twórcze uzdolnienia to nie sprawa mózgu i rozumu. Prawdy życia odsłaniają się w podnieceniu, które tylko częściowo podlega rozumowi. Prawdy sztuki wyłaniają się z przysadki mózgowej, z mętnych namiętności i tajemnic ciała, bardzo często z szaleńczych intuicji, a niemal zawsze bez powodu, przekornie i żywiołowo jak gorączka (Krleža, 1984, 376).

Krleža dowartościowywał wrażliwość emocjonalną i innerwacyjną, czyli subiektywną wrażliwość zapośredniczoną fizycznie, cieleśnie i intelektualnie. Literatura i sztuka były według niego formą innerwacyjnego reagowania na całość istniejącej rzeczywistości, człowieka i społeczeństwa. Ten typowy dla awangardy punkt widzenia Krleža rozwijał w późniejszej twórczości, niezmiennie podkreślając, że sztuka jest odzwierciedlaniem materialno-obiektywnych procesów, przetworzonych przez pryzmat indywidualnej wyobraźni i subiektywnych inspiracji. Utopijna wyobraźnia dotykała kwestii zmiany człowieka i rzeczywistości, a postulowane przemiany miały być efektem jego działania i rewolucji duchowej oraz społecznej.

Socjalizacja awangardy była zjawiskiem postępującym, rozwijającym się wraz z dojrzewaniem świadomości jej reprezentantów, co można zaobserwować w latach trzydziestych XX wieku. W roku 1920 w Manifeście ekspresjonistycznej szkoty Stanislav Vinaver pisał:

Wchodzimy dzisiaj w d u c h a prze m i a n, w ducha przepływu, w rewolucję wyrazu i tego co się wyraża [...]. Nie dokona rewolucji każdy, kto tylko zapragnie. Trzeba wiedzieć, jak rozpocząć uwalnianie słów, pojęć wyobrażeń - z ich ograniczeń i okowów. My, ekspresjoniści rozpoczynamy rewolucję, wchodzimy w chaos, w n i e s k o ń c z oność uwalniania wszystkiego od wszystkiego (Vinaver, 1980, 82).

Koncepcje rewolucji obejmowały zmieniające się wizje całości, w której przemianom podlegały światy wewnętrzne i zewnętrzne człowieka. Nowe poglądy formowały wyobrażenia artystów, pośród których do najważniejszych należało przekonanie o uniwersalnej jedności świata i mistycznych korespondencjach zachodzących w bycie. Kosmiczna wizyjność i ,kosmička lirika u srpskoj književnosti odgovarala bi tipu apstraktnog ekspresionizma" (Vučković, 1984, 104). Abstrakcjonistyczne ujęcia rzeczywistości w sztuce właśnie torowały sobie drogę, stając się jednym z wyznaczników sztuki współczesnej i jej obrazowania.

Poeci serbscy - ekspresjoniści Miloš Crnjanski i Rastko Petrović oraz nadrealiści - prezentują podobną epistemę, według której wszystkie 
elementy rzeczywistości są połączone siecią tajemniczych więzi, przenikań, transformacji, niepojętych dla ludzkiego rozumu, ale możliwych do uchwycenia dzięki intuicji i wyobraźni. Ten irracjonalny i zmityzowany wątek przypomina zarówno unifikacyjną teorię Anaksagorasa (koncepcję nous), jak i nowoczesną kosmocentryczną „teorię wszystkiego" (theories everything - TOES), czyli teorie bytu nieantynomicznego, łączącego materię i psyche, naturę i kulturę. Wiersz Crnjnskiego Sumatra jest uznawany za poetycką wykładnię rozumienia rzeczywistości. W komentarzu do wiersza pisarz wyjaśnił ideę korespondencji, która determinuje wyobraźniowe myślenie o kosmicznej jedni. Jednocześnie uznał, że to poetyckie majaczenia, charakterystyczne dla nowych nurtów artystycznych. Taka wewnętrznie sprzeczna pozycja nie jest awangardzie obca. Dostrzegli ją zenityści, którzy fenomen paradoksu poddali szerszej refleksji.

Przyjęta przez awangardę wizja rzeczywistości wraz z nowymi poetykami pozwalała artystom w swobodny sposób łączyć różne obrazy, stawiając na jednej płaszczyźnie dowolnie wybrane elementy wyobraźni. Przykładem takiego postępowania w malarstwie są obrazy Chagalla, uniezwyklające percepcyjne nawyki i przyzwyczajenia. Symultaniczne i ejdetyczne połączenie różnych fragmentów rzeczywistości (obrazów, znaków) na jednej płaszczyźnie czasowo-przestrzennej jest nowym sposobem pojmowania całości i nowym doświadczeniem, przełamującym granice postrzegania i percypowania. Podobnie działają mechanizmy snu czy marzenia sennego. Nadrealiści uznali je za najważniejsze drogi poznania kondycji człowieka. Wyobraźnia i sen nie uznają granic, ich czasoprzestrzeń jest płynna, a semantyka znaków wieloraka. Poeci eksplorują je chętnie, niezależnie od kierunku (v. Benčić, Fališevac 2012) Referując poglądy Bretona, Krystyna Janicka podsumowuje:

Doniosłość poznawcza funkcji wyobraźni wynika natomiast z tego, że stanowi ona ogniwo pośredniczące między światem podmiotowym a światem przedmiotowym i że jej wytwory znajdują się w podwójnej relacji: do rzeczywistości psychicznej (względnie intelektualnej, umysłowej) i do świata rzeczy (Janicka, 1985, 77).

Te podwójne relacje determinują możliwość przenikania świata materii i świata psyche oraz zaskakujące zjawiska określane jako synchroniczne. Nie dziwi zatem fakt, że nadrealiści przypisywali wyobraźni ogromną rolę, sądząc, że posiada zdolność przenikania i równoważenia bytu. 
Między innymi dlatego w ich koncepcji pojawiły się rozważania o moralnej funkcji poezji, łączonej z indywidualnym podmiotem, uczestniczącym w tej bardzo poważnej grze o równowagę. Ale myślenie o etyczności podmiotu pojawiło się już wcześniej i niezależnie od nadrealizmu. Tak jak myślenie o interferencjach natury i kultury oraz ich wpływie na twórczość.

Bardzo podobną estetykę - aczkolwiek znacznie bardziej radykalną opartą na intuicyjnym poznawaniu rzeczywistości wewnętrznej i zewnętrznej oraz na automatyzmie psychicznym prezentowali nadrealiści, m.in. Marko Ristić i Oskar Davičo. W jej centrum umieścili koncepcje psychoanalizy, tłumaczące funkcjonowanie umysłu, instynktu, podświadomości, wyobraźni. Obaj cenili idee estetyczne Krležy, ale w swoich poszukiwaniach byli znacznie bardziej radykalni, otwierając się na wszelkie nowoczesne teorie i eksperymenty. W szczególności Oskar Davičo zadziwił nowymi możliwościami artystycznego wyrażania świadomości surracjonalnej. Dla obu psychoanalityczna filozofia człowieka była ważna. Zgodnie z nią:

Struktura umysłu, a także struktura jego poszczególnych elementów na przykład instynkt, determinują fakt istnienia związków z rzeczywistością zewnętrzną. Zarówno tę percypowaną zmysłowo, jak i tę oznaczoną przez id, która stanowi stłumione dzieje gatunku i jednostki, jak i tę nazwaną superego, która jest społecznie akceptowaną tradycją (Rosińska, 1985, 81).

Awangarda z premedytacją usiłowała uniezwyklić percepcję, m.in. przez transgresyjność oraz wprowadzanie fenomenu przenikania czy fenomenu przypadku. Skrajnym przykładem nowej techniki konstruowania jest kapelusz dadaistów, do którego wrzucano słowa, by je zmieszać i pokazać w nowym ujęciu. Praktyki tego rodzaju traktowano ludycznie i prześmiewczo. Inaczej myślano o zapisie automatycznym. Inaczej, czyli poważniej, bez ironii. Doświadczenie automatyzmu traktowano jako zabawę na serio, spodziewając się po nim być może więcej, niż należało się spodziewać. Dla awangardy automatyzm był nie tylko techniką zapisu, ale i ścieżką poznawczą, tyle że zawarta w niej synchroniczność ewokuje wiele tropów interpretacyjnych, przekraczających możliwości poznawcze odbiorcy. Według Junga zjawiska synchroniczne charakteryzują się wiedzą absolutną. Ani autor, ani czytelnik wiedzy tej nie posiadają, mogą w niej tylko fragmentarycznie uczestniczyć w akcie interpretacji udostępniającym wybrany punkt widzenia, jakiś ułamek znaczenia czy sensu. 
Absolutność wiedzy ujawniająca się poprzez akauzalny porządek zjawisk oznacza, tłumaczy Mirosław Piróg - iż wykracza ona poza dany moment czasowy i obejmuje, w jakiejś mierze, także przeszłość i przyszłość. [...] Wzajemna odpowiedniość sfery psychicznej i fizycznej zyskuje zakorzenienie w głębszej sferze bytowej, którą można opisać jako sferę sensu lub ducha. W języku psychologii Junga matryca ta uzyskała nazwę. Jest to nieświadomość zbiorowa, a w szczególności jej struktury, zwane archetypami (Piróg, 2006, 58-59).

Wgląd w nieświadomość, w niewyrażalne, mógł oznaczać intuicyjny „wgląd w podłoże bytowania bytu” (Szołtysek, 1992, 65). Awangarda podążała tropem podobnych intuicji, które przetwarzała w praktykę artystyczną i nowe języki wyrażania.

Artyści pragnęli odświeżenia języka literackiego, który uznawali za wyeksploatowany, zużyty, zależny od nawyków i przyzwyczajeń narzuconych przez kulturę. Stosowali w tym celu różne eksperymenty, z których zapis automatyczny należy do ciekawszych, a zarazem najtrudniejszych. Nadrealiści wielokrotnie mierzyli się z jego możliwościami.

Oskar Davičo w tekście Anatomija uruchomił ciągi obrazów i pozornie przypadkowych skojarzeń, których irracjonalny ładunek w zderzeniu z próbą racjonalnego ich wyjaśnienia jest raczej mało czytelny. Obrazy są prezentowane symultanicznie, układają się w kolaż słów i obrazów frazeologicznych pozornie luźno połączonych. Są nasycone znakami, znaczeniami, wynikającymi z nieustannych transformacji semantycznych. Ich niegotowość, swoista abstrakcyjność, irracjonalna źródłowość, otwarcie na Inne - nie sprzyja deszyfrowaniu znaków i znaczeń, które są zależne od tekstu, kontekstu i semantyki określonej przez kulturę oraz najszerzej rozumianą rzeczywistość.

Bohater i mediumiczny podmiot narracji rejestruje obrazy, które są dane i zadane. Dane przez podświadomość czy nieświadomość, a zadane do odczytania. Jest ono ograniczone w zasadzie do obserwowania słów i ich przeobrażeń. Dotarcie do sensu tych przeobrażeń jest prawie niemożliwe. Choć zapisowi automatycznemu towarzyszyły nadzieje na zrozumienie ewokowanej przez obrazy automatyczne realności, nadzieje na zdobycie „niemego” języka bytu. Sam autor powracał do motywów tego zapisu, poddając je kolejnym przeobrażeniom i testując ich możliwości sensotwórcze. Czyli nie zgadzał się, by traktować je jako obrazy nicości, obrazy o zerowej semantyce, otwartej na nic. Osobliwość tego obrazowania, 
dziwność przedstawianej rzeczywistości (wielu różnych rzeczywistości) zaskakuje i prowokuje. Na plan pierwszy wysuwa się przeobrażanie słów i transformowanie znaczeń. Podmiot wypowiedzi zapisuje słowa samo-ubica, by je przekształcić na SAN MOJ UBICA (Davičo, 1979, 48). Motyw snu staje się ważny (zapis dużymi literami), ponieważ wprowadza tajemnicę. Motyw ten będzie powtarzany, sugerując nie tylko wagę snu (typową dla nadrealizmu), ale i kompozycyjne podporządkowanie tekstu oniryzmowi. Tylko sen może operować obrazami, nie dbając o ich logiczne powiązania. W próbie interpretacji tekstu posłużyłam się tytułem Niemy język (nie)bytu, czyli u źródet obrazowania we wczesnej poezji Oskara Daviča (Czapik-Lityńska, 2005, 114-126), włączając go w inne teksty poety, z którymi tworzył pewną całość dla motywów i obrazów. Davičo traktował obrazy z czasu nadrealizmu jako przed-obrazy, przed-znaki, przed-znaczenia. W późniejszej twórczości będzie do nich wracał, by eksplorować ich możliwości semantyczne, by z nich wydobyć informacje bytowe, odmienne od informacji dyskursywnej, logicznej i zdeterminowanej kulturowo. Niewielu krytyków zauważyło te tropy i te poszukiwania, a to one właśnie współtworzą poetykę niemożliwego. Dziwne obrazy Daviča to obrazy otwarte, adekwatne do poszukiwanego modelu percepcji. Występują w podwójnej roli - idola i ikony. Idol to obraz literacki zamknięty w artystycznej przestrzeni własnego, autonomicznego języka, który poddaje się interpretacjom zwróconym ku autotelicznym wartościom komunikatu i jego artystycznej organizacji. Ikona to obraz otwarty na byt albo nadrealistyczną nadrzeczywistość, w którym może przejawiać się synchroniczność. Davičo wprowadził do swoich tekstów pojęcie „patrzącej niematerii”, przestrzeni ciszy i milczenia, swoiście rozumianego niebytu, którego nie sposób ująć zmysłami, chyba że figuratywnym okiem lub uchem wyobraźni. Julian Kornhauser zauważa, że „Davičo, wprowadzając pojęcie «niematerii» jako instancji kontrolującej działanie człowieka, przypomina jednocześnie o istnieniu innego wymiaru (pustego i czystego) dla teraźniejszości” (Kornhauser, 1991, 92). O tym wymiarze nie przeczytamy w teorii literatury nauczającej, czym jest literackość. Wymiarem tym zajmuje się teoretyczna fizyka kwantowa, a w humanistyce filozofia. Mamy zatem różne konteksty. Wybór należy do interpretatora. Przed wielu laty profesor Slobodan Ž. Marković opowiadał mi, że kiedy pytał poetę o znaczenie jakiegoś obrazu, zawsze otrzymywał odpowiedź - popatrz na 
kontekst (pogledaj u kontekst). Ba. Ale na który kontekst? Z której teorii? I do której rzeczywistości odnoszony? Obrazy automatyczne są niegotowe, wymagają dopełnienia w interpretacji. I nie chodzi o oryginalność, ale o dopełnienie rozumu transwersalnego, zdolnego do obejmowania innego i różnego.

Możliwe, że ten inny wymiar - zwany kiedyś pustą transcendencją jest ważny dla zdarzeń synchronicznych. Spróbuję jeden z obrazów odczytać w kontekście synchroniczności. Dla wyjaśnienia zawartych w obrazie treści nie jest konieczna psychoanaliza, ale biografia autora i wiedza, zwłaszcza najnowsza wiedza o rzeczywistości i czasie.

W 1930 roku Davičo opublikował teksty automatyczne pod znamiennym tytułem Anatomija. Zapisy składają się z luźno powiązanych (a raczej niepowiązanych) obrazów, w treści dość absurdalnych. Zacytuję fragment jednego z nich: „Prošao sam pored dečka sa koga opadaju molekuli gvožđa" (Davičo, 1979, 60).

Przywołany obraz (także inne obrazy z tego zapisu) jest nie tyle oryginalny, ile zaskakujący, a nawet szokujący. Można go interpretować jako obraz idol i jako obraz bytowy. W obrazie idolu wystarczy zmienić kod artystyczny, zwizualizować obraz słowny i namalować piękne drzewo z wpisaną w nie postacią chłopca. Obraz chłopca-drzewa wcale nie jest niezwykły, raczej dziwny, co jest cechą poetyki nadrealizmu. Sygnałem zaburzającym piękno obrazu jest opadanie liści - molekuł żelaza (opadaju molekuli gvožđa), co zapowiada porę jesieni i zamieranie (zgodnie z cyklami natury), ale nie wprowadza estetyki brzydoty czy szoku. Namalowany obraz może być ładny.

Natomiast obraz bytowy byłby obrazem notującym zdarzenie synchroniczne i nie można go uznać za ładny, raczej za mroczny i niepokojący. Podmiot-medium używa w tekście czasu przeszłego, powiada „,przeszedłem obok". Jeśli potraktować to przejście jako literacką reprezentację zdarzenia życiowego, to należy uzupełnić wiedzę tekstu o wiedzę kontekstu biograficznego (czyli przypomnieć słowa poety - popatrz na kontekst). Otóż jedyny syn pisarza zmarł na nieuleczalną chorobę krwi, pozostawiając żonę i dwie córki. Realny dramat śmierci można powiązać z treścią obrazu i uznać za zdarzenie synchroniczne. Byłby to obraz tragiczny, ujawniający absurd egzystencji. Analizę wybranych zdarzeń synchronicznych, manifestujących się w nadrealizmie francuskim przedstawiła Krystyna Janicka 
(1985, 110-122). Breton nazywał je przejawami ,przypadku obiektywnego" i zauważał je m.in. w tekstach automatycznych i obrazach malarskich. Zwierają one elementy profetyczne, ale odkrywana wiedza nie jest radosna, raczej przytłaczająca.

Pozostaje jeszcze kwestia wyjaśnienia czasu i specyfiki rzeczywistości, czyli stosunku rzeczywistości tekstowej do pozatekstowej, jeżeli pozostaniemy przy tej dziwnej relacji. Młody autor pisze w czasie przeszłym o wydarzeniu z odległej przyszłości. W naszej zmysłowej percepcji obraz idol jest wiarygodny, a obraz bytowy niekoniecznie, bo nie zgadza się z naszym pojmowaniem czasu i rzeczywistości. Najnowsza literatura z zakresu fizyki (a konkretnie uwzględnione w bibliografii książki Carla Rovelliego, książki, które traktuję jako moje największe lekturowe odkrycie 2019 roku) przekonuje, że rzeczywistość nie jest taka, jak ją postrzegamy, a czas nie jest taki, jak go sobie wyobrażamy. Tego ekscytującego wątku rozwijać nie mogę, bo musiałabym szkic zmienić w rozprawę. Zamknę go konkluzją, iż w zdarzeniu synchronicznym dochodzi do dziwnego pomieszania tego, co w naszej ludzkiej potocznej percepcji nie powinno się pojawiać na tej samej płaszczyźnie czasowo-przestrzennej. Wszak nie można mówić jednocześnie o tym, co się dopiero zdarzy i o tym, co się zdarzyło i zdarza aktualnie. Teoria nadrzeczywistości i teoria przypadku obiektywnego (teoria synchroniczności) - mimo że wydają się irracjonalne - tłumaczą i sankcjonują dziwne i szokujące obrazy oraz doświadczenia nadrealizmu.

Twórczość Oskara Davičo stwarza krytyce naukowej sporo kłopotów, bo też poeta, jak przystało na prawdziwego nadrealistę, nie pałał zachwytem do tradycyjnej literatury i literackości. Vujica Rešin Tucić (2005), znakomity poeta poawangardowy (tłumaczony na język polski), nazwał Daviča poetą demonicznym, któremu zdarzało się literaturę destruować i opuszczać, podążając za nieznanym, fantomicznym, irracjonalnym. Ten, zdaniem Krležy, najlepszy poeta serbskochorwackiego obszaru językowego uczynił z języka pole działań eksperymentatorskich i wizjonerskich. W penetrowaniu tajemnic języka i bytu przekraczał granice estetyki, łamał konwencje i nawyki. Prowadził grę z językiem, eksperymentował ze słowem, znakiem i znaczeniem, poddając je - jakby po derridiańsku - w wątpliwość.

Innym ważnym nadrealistycznym tekstem, prezentującym dziwną wyobraźnię nadrealizmu z wszystkimi jej wyróżnikami, przenikaniami 
i transformacjami leksykalno-obrazowymi jest antypoemat Turpituda Marka Risticia. Sam poeta nazwał go ,paranoiczno-dydaktyczną rapsodią (quasi una fantasia)" (Ristić, 1984, 357). Poemat jest nadrealistycznym soliloquium wyobraźni rozpisanej na wiele głosów świadomości i podświadomości. Jest też zapisem symulującym myślenie paranoiczne, łączące nieantynomicznie to, co jest wyobrażane, z tym, co potencjalnie może być realne. Cecha ta jest również specyficzna dla synchroniczności. Bohaterka uczestniczy w wielu dziwnych transformacjach, które umożliwiają przeobrażanie samego bytu. W tym quasi-literackim poemacie, przypominającym krytyczną psychoanalizę z jej początkowego okresu, obrazy układają się w myślowy łańcuch, którego ogniwa pozostają w łączności ze wszystkimi częściami świata. Ristić wykreował bohaterkę o heroicznym duchu i zbawczej mocy, zdolnej myślą i emocją ingerować w byt, a nawet go równoważyć. Turpituda jest rozwinięciem archetypu zbawcy i, co ciekawe, pierwszą w literaturze bohaterką zbawczynią. Tę rolę przyjmowali zawsze mężczyźni. Awangarda zresztą również wykreowała męską postać zbawcy - słowiańskiego geniusza, ale został on zdetronizowany przez kobietę. Turpituda i jej paranoiczna percepcja, umożliwiająca wymianę energii myśli z energią bytu (dzięki tożsamości bytu i myślenia), jest hołdem dla myśli irracjonalnej, dla synchroniczności i dla filozofii Hegla, którego koncepcję rzeczywistości jako jedności wszystkich elementów bytu nadrealiści przyjęli jako dopełnienie definicji nadrzeczywistości. Świat (byt, absolut) podlega przeobrażeniom, pozostaje w ciągłym ruchu i rozwoju, w którym uczestniczy również człowiek. W poemacie Risticia - język, słowo, obraz uczestniczą w grze języka, w irracjonalnych metamorfozach:

Słowo awangardy nie chce być słowem wyłącznie estetycznym, Ristić pojmuje je w kategoriach pulchritudo vaga, jako słowo przenikające do bytu, równoważące jego antynomiczne struktury. Turpituda, której imię podlega różnym metamorfozom (jak słowa w poemacie), jest podobnie jak słowo siłą przenikającą, równoważącą, zbliżającą rzeczywistość do marzenia, mit do rzeczywistości. Jest też figurą mitu (jak Gradiva) i jego podwójnej mowy - dobrej i złej, energii wymagającej równoważenia" (Czapik-Lityńska, 2005, 109).

Nie znam bardziej dynamicznego, ruchliwego, halucynacyjnego zmiennego świata przedstawionego w awangardzie. I nie znam drugiej takiej bohaterki jak Turpituda, drugiej takiej tęsknoty za wybawieniem, za zmianą niemożliwej do akceptacji kondycji człowieka (egzystencjalnej 
i ontologicznej). W przeciwieństwie do dziwnej, tajemniczej i dość mrocznej wiedzy o synchroniczności, wiedza o figurach archetypicznych wnosi nadzieję. Figury archetypiczne można odczytywać jako drogowskazy. Współcześni badacze zauważają zamieranie archetypu, co odnotowują jako zjawisko niebezpieczne. Możliwe, że przyczyną jest kultura osłabiająca myślenie irracjonalne i redukująca mit.

Odkrycia w sferze artystycznego wyrażania niezupełnie awangardę zadowalały, dążyła do ujawnienia wspólnego jądra poezji i rzeczywistości - poetyckiego absolutu. W otwarciu na irracjonalne, na podświadomość i nieświadomość upatrywała szansy na zmianę. $Z$ tego powodu stała się najbardziej transgresyjną formacją, rewolucjonizującą język, percepcję, estetykę, wyobrażenia o świecie.

Myśląc dzisiaj o awangardzie, nie sposób nie postawić sobie pytania, na czym polegała waga znanych i mniej znanych kierunków. Wszystkie one uczestniczyły w tej samej literackiej i pozaliterackiej przygodzie, zależnej od wyznawanego światopoglądu. Awangarda dążyła do poszerzenia świadomości, zgodnie z proponowanymi założeniami ideowo-artystycznymi i wizjami całości. Prowadziła dialog z różnymi językami sztuki i wiedzy. Była też pełna sprzeczności i paradoksów. Z jednej strony chciała demokratyzacji aktu twórczego (aby każdy mógł tworzyć), z drugiej zaś była zbyt trudna, dziwna i hermetyczna. W artykule Proroczy aspekt awangardy Bożena Tokarz pisze:

Awangardową postawę artystyczno-estetyczną charakteryzuje arystokratyzm estetyczny oraz transgresyjność wynikająca z krytycyzmu wobec sztuki i rzeczywistości, czego wynikiem jest zagarnianie coraz szerszych obszarów nie-sztuki, powodujące zmiany artystyczne w zakresie sposobów znakowania symbolicznego (Tokarz, 2019, 24).

Trudno się nie zgodzić z takim ujęciem, bo współczesność je potwierdza, ale warto pamiętać, że chorwacka i serbska awangarda chciały więcej, chciały wtajemniczenia w najszerzej pojętą rzeczywistość i nie wahały się wchodzić w spory z literaturą i literackością, które oczywiście z biegiem czasu zmieniają swoje oblicza, poszukując prawdy o splotach słowa i języka z istnieniem (albo tylko słowa ze słowem). I docierają do niemożliwego odczytania, do umykającego sensu, rozproszenia, nieprzewidywalności, powtarzając gry awangardy $\mathrm{i}$ jej uwikłania w dialog pierwiastka racjonalnego z irracjonalnym. 


\section{Literatura}

Benčić, Ž., Fališevac, D. (ur.) (2012). Prostori snova. Oniričko kao poetološki i antropološki problem. Zagreb: Disput.

Bieńkowski, Z. (1974). 50-lecie Manifestu nadrealistycznego. „Poezja” nr 9, s. 68.

Crnjanski, M. (1966). Poezija. Beograd: Prosveta.

Crnjanski, M. (1980). Objaśnienie Sumatry. Przeł. G. Łatuszyński. „Literatura na Świecie" nr 9 (113), s. 7.

Czapik-Lityńska, B. (1987). Twórczość poetycka Oskara Davičo. Katowice: Uniwersytet Śląski.

Czapik-Lityńska, B. (1996). „Jeszcze nie”. Utopicum jugostowiańskiej awangardy. Katowice: Wydawnictwo Uniwersytetu Śląskiego.

Czapik-Lityńska, B. (2005). Chorwacka i serbska awangarda w perspektywie badań porównawczych. Katowice: Wydawnictwo Uniwersytetu Śląskiego.

Czapik-Lityńska, B. (2012). Iskustvo sna u suvremenoj hrvatskoj poeziji. A.G. Matoš, J. Kaštelan, S. Mihalić, D. Oraić-Tolić. W: Prostori snova. Oniričko kao poetološki i antropološki problem. Ur. Ž. Benčić i D. Fališevac. Zagreb: Disput, s. 323-379.

Davičo, O. (1979). Pesme. Hana. Beograd: Prosveta.

Dąbrowska-Partyka, M. (1999). Teksty i konteksty. Awangarda w kulturze literackiej Serbów i Chorwatów. Kraków: Wydawnictwo Uniwersytetu Jagiellońskiego.

Đorđić, S. (ur.) (1979). U potrazi. Radovi o književnom delu Oskara Daviča. Beograd: Narodna knjjiga.

Jacobi, J. (1996). Psychologia C.G. Junga. Przeł. S. Łypacewicz. Warszawa: Wydawnictwo Ewa Karczewska L.C.

Janicka, K. (1985). Światopoglad surrealizmu. Jego założenia i konsekwencje dla teorii twórczości i teorii sztuki. Warszawa: Wydawnictwa Artystyczne i Filmowe.

Kornhauser, J. (1991). Strategie liryczne serbskiej awangardy: szkice o poezji. Kraków: Universitas.

Krleža, M. (1984). Dzienniki i eseje. Przeł. J. Wierzbicki. Łódź: Wydawnictwo Łódzkie.

Milanja, C. (2000). Pjesnišstvo hrvatskog ekspresionizma. Zagreb: Matica hrvatska.

Novaković, J. (1996). Na rubu halucinacija. Poetika srpskog i francuskog nadreali$z m a$. Beograd: Filološki fakultet.

Pawliszyn, A. (1999). Świat człowieka i kosmos poprzez metaforę, Poznań: Wydawnictwo Fundacji Humaniora.

Pieniążek-Marković, K. (2000). Twórczość poetycka Antuna Branka Šimicia: Z problemów poezji chorwackiego ekspresjonizmu. Poznań: Wydawnictwo Naukowe UAM.

Pilch, A. (2006). Umykanie sensu - chaos języków - tekst wiecznie niedoczytany, (Derrida, Descombes, Deleuze). W: Efekt motyla. Humaniści wobec teorii chaosu. Red. K. Bakuła i D. Heck. Wrocław: Wydawnictwo Uniwersytetu Wrocławskiego, s. $143-148$.

Piróg, M. (2006). Synchroniczność - parapsychiczna wizja rzeczywistości. W: Inspiracje jungowskie, metafory, sny, archetypy. Red. M. Adamiec, F. Białecki, K. Czech. Warszawa: Eneteia, s. 51-60. 
Rešin Tucić, V. (2005). Demonski Davičo. W: Vreme fantoma: o piscima i knjigama. Novi Sad: Anagram.

Ristić, M. (1984). Turpituda. W: Dela Marka Ristića. T. 1: Knjiga poezije. Ur. M. Nikolić, N. Bertolino. Beograd: Nolit.

Rosińska, Z. (1985). Psychoanalityczne myślenie o sztuce. Warszawa: PWN.

Rovelli, C. (2019). Rzeczywistość nie jest tym, czym się wydaje. Przeł. M. Czerny. Łódź: Feeria science.

Rovelli, C. (2019). Tajemnica czasu. Przeł. J.K. Ochab. Łódź: Feeria science.

Samuels, A., Shorter, B., Plaut, F. (1994). Krytyczny słownik analizy Jungowskiej. Przeł. W. Bobecki, L. Zielińska. Warszawa: UNUS.

Sharp, D. (1998). Leksykon pojęć i idei C.G. Junga. Przeł. J. Prokopiuk. Wrocław: Wydawnictwo Wrocławskie.

Šimić, A.B. (1988). Sabrana djela. Zagreb: August Cesarec.

Szołtysek, A.E. (1992). Metafizyczność języka. Katowice: Uniwersytet Śląski.

Szołtysek, A.E. (1994). Metafizyka jedni. Katowice: Fundacja dla Wspierania Śląskiej Humanistyki.

Tokarczuk, O. (2019). Świat z odwrotnej strony. „Tygodnik Powszechny” nr 42, s. 21.

Tokarz, B. (2004). Między destrukcją a konstrukcja. O poezji Srečka Kosovela w kontekście konstruktywistycznym. Katowice: Wydawnictwo Uniwersytetu Śląskiego.

Tokarz, B. (2019). Proroczy aspekt awangardy. W: Stowiańskie formuly nowoczesności. Ideały i iluzje przemiany. Red. L. Miodyński. Katowice: Wydawnictwo Uniwersytetu Śląskiego, s. 21-34.

Ujević, T. (1979). Kozmogonije. W: Odabrana djela Tina Ujevića. Prir. Š. Vučetić, knj. 1, Zagreb-Beograd: August Cesarec, s. 321.

Vinaver, S. (1980). Manifest szkoty ekspresjonsitycznej. Przeł. M. Dąbrowska-Partyka, „Literatura na Świecie” nr 9 (113), s. 82-84.

Visković, V. (ur.) (1999). Krležijana, 2 M-Ż. Zagreb: Leksikografski zavod „Miroslav Krleža".

Vučetić, R. (1984). Avangardna poezija. Banja Luka: „Glas”. 